\title{
DYNAMICS OF LIVESTOCK PRODUCTION DEVELOPEMENT IN THE SLOVAK REPUBLIC BETWEEN THE YEARS 2004 AND 2017 AND POTENTIAL IMPACT OF THE CHANGES ON THE AGRICULTURAL SECTOR AND LANDSCAPE
}

\author{
NÉMETHOVÁ, J. ${ }^{1 *}$-HudÁKOVÁ, M. ${ }^{2}$ \\ ${ }^{1}$ Department of Geography and Regional Development, Faculty of Natural Sciences \\ Constantine the Philosopher University in Nitra \\ Trieda A. Hlinku 1, 94974 Nitra, Slovak Republic \\ ${ }^{2}$ Department of Management, Faculty of Economics and Management \\ Slovak University of Agriculture in Nitra, Trieda A. Hlinku 2, 94901 Nitra, Slovak Republic \\ *Corresponding author \\ e-mail:jnemethova@ukf.sk; phone: +42-1-905-274-138 \\ (Received 11 $1^{\text {th }}$ Mar 2019; accepted $1^{\text {st }}$ May 2019)
}

\begin{abstract}
The paper deals with the dynamics of changes in livestock production in Slovakia in the period between 2004 and 2017 from the viewpoint of productive and non-productive factors with a special focus on environmental factors in the breeding of four groups of farm animals. The development was evaluated on the basis of the indicator of stock intensity. The data was analysed at the levels of NUTS 3 (regions) and LAU 1 (districts) for Slovakia. The study showed that the changes in the agricultural sector after the year 2004 due to Slovakia's entering the European Union have manifested themselves in an overall decrease of livestock production as well as in further aggravation of regional disparities. The aforementioned changes not only pose a direct risk to the agrarian sector but they also affect the environment in a broader context. The positive ecological impacts associated with the attenuation of primary livestock production spotted at first glance can negatively affect the environment, biological diversity and quality of life. The current status quo requires a consequent application of the principles of organic farming and its support in form of government subsidies and legislation.
\end{abstract}

Keywords: animal production intensity, ecological agriculture, regional disparities, environmental impact, Slovakia

\section{Introduction}

Before the transformation process in the agrarian sector livestock production in Slovakia was to one of those fields, which had been financed by state subsidies. After the transition to the new model of economic relations the government incentives were minimized and abolished respectively. This resulted in a significant decrease of livestock population, particularly in the traditional (majority) groups such as beef cattle and pigs. It became problematic to cover the costs of breeding and producing livestock. The reduction in the number of the individual types of livestock had already started in the 1990's and it has been continuing ever since. In this period not only the regional disparities in primary livestock production in Slovakia became apparent (Némethová et al., 2017b) but the development insinuated that the stability of the agricultural commodity markets was at stake. This developement persists and livestock production in Slovakia has been on the decline for a long time (Chrastinová et al., 2014). This fact is also connected with the economic conditions such as higher costs of breeding farm animals (Buday et al., 2012). The decline in livestock production is related to the decrease in the numbers of the individual types of farm animals but also to the import of 
finished products of animal origin to the Slovak market. The structural changes in Slovak agriculture after Slovakia's accession to the European Union (EU) in the year 2004 and the Common Agricultural Policy (CAP) aggravated the regional disparities in livestock production (Némethová et al., 2004). As a result in Slovakia not only livestock population drastically dropped but in some regions the breeding was completely abandoned. The positive aspect in the process is the growing efficiency of farm animals, which is however conditioned by other than economic factors. The EU's Common Agricultural Policy motivated the farmers with its instruments to reduce livestock production and to favour vegetable production focussing on large-scale crop production and primarily crops in the area of renewable energy sources, which ultimately brought about other specific implications and consequences.

The changes in Slovak agriculture associated with the consequences of a state's entering the European Union and adopting the EU's CAP are theoretically reflected in the works of experts from various aspects (Spišiak et al., 2005; Falt’anová, 2008; Spišiak and Némethová, 2008; Buday et al., 2012; Némethová and Civáň, 2017; Némethová et al., 2014, 2017a). The problems do not concern only Slovakia. After the dissolution of Czechoslovakia Czech farmers also had to come to terms with the new situation. The impact of the CAP on agriculture and rural areas in the Czech Republic and the issue of regional disparities have been analysed by several authors (Kabrda and Jančák, 2006; Svobodová and Věžník, 2011; Věžník and Konečný, 2011; Král et al., 2012; Doucha et al., 2012 and others). Over the past 30 years the Czech Republic has seen a rapid decline in some types of farm animals as well as a change in their internal structure and method of breeding (Věžník et al., 2013, 2017). The impacts of the EU's CAP on the development of agriculture, the analyses and evaluation of the impacts are written down in the works of many foreign experts (Kulikowski, 2005; Kołodziejczak, 2006; Buchenrieder and Möllers, 2009; Kołodziejczak and Kossowski, 2011). The approach of the individual farmers in Portugal as far as the impact of the EU's CAP is concerned is presented by Dos Santos et al. (2010). Rudnicki (2013) assessed the situation in Poland from the viewpoint of a recipient of European subsidies. The approach and opinions of selected farmers in the new EU member states regarding the changes in the CAP after the year 2003 were dealt with by Gorton et al. (2008). Ilbery and Maye (2005) analysed selected changes in the trend of cattle breeding and its importance for the food market in Great Britain.

Ecologization of agriculture and protection of the environment are important on a global scale. The European Union supports this aera of agro-environmental production. Apart from producing healthy food organic farming strives to eliminate damaging and devastating of the environment by preventive measures and special farming and breeding practices (Petrovič et al., 2017). Unlike convenational agriculture it prefers the quality of production, versatile production and a varied cropping pattern. It excludes chemistry and machinery from its production. The system of organic farming is the research topic of several experts in Slovakia, e.g. Schlosserová and Juršík (2009), Némethová and Mesárošová (2013), Kozáková et al. (2015), Némethová et al. (2017b) in the Czech Republic, e.g. Hrabalová and Zander (2006), Brožová (2011), Doležalová et al. (2014). The analysis of the transition from the conventional farming system to organic farming is dealt with by e.g. Lockie and Halpin (2005), Stolze and Lampkin (2009), Moschitz and Stolze (2009), Mzoughi (2011). The measures applied by the government and the market economy aim at supporting organic farming and 
consumption of organic products (Milestad and Darnhofer, 2003; Häring et al., 2004; Nieberg and Kuhnert, 2007).

The aim of the paper was to analyse the developmental trends and the level of animal production in Slovakia in the period 2004 to 2017 and to point out regional disparities at the level of regions and districts of Slovakia - in the context of environmental effects. Main attention was focused on the dynamics of livestock production developement and potential impact of the changes on the agricultural sector and landscape.

\section{Material and methods}

\section{Dataset characteristics}

The main statistical set comprised the official data of the Statistical office of the Slovak Republic referring to the basic indicators of livestock production in the period between 2004 and 2017 (MS Excel). The data was analysed at the level of NUTS 3 (regions) and LAU 1 (districts) of Slovakia.

The principal livestock production indicator used in this study was the stock density on the declared area: heads on 100 hectares of agricultural area (cattle and sheep) or arable land (pigs and poultry) and its alternation during the reference period. The impact of the changes in primary livestock production on the subsequent production on the market is illustrated by the data regarding sales from livestock farming during the evalutation period from 2004 to 2017.

\section{Dataset processing}

In order to statistically process and cartographically visualize stock density in the initial situation in the year 2004 and the situation in the year 2017 as well as sales development we applied descriptive statitics and the ArcView programme for visualizing spatial information. For the needs of illustrating the modelling of potential development of stock density in the coming period (identification of expected trends) we applied a procedure based on the evaluation of the dynamics of timelines aided by the ARIMA model in the R software.

\section{Results and discussion}

\section{Dataset general characteristics}

For the needs of the study the basic statistical set was analysed at the level of the regional statististical territorial units NUTS 3 (regions) and LAU 1 (districts). Slovakia is administratively divided into eight self-governing regions: the Bratislava Region, the Trnava Region, the Trenčín Region, the Nitra Region, the Žilina Region, the Bánska Bystrica Region, the Prešov Region and the Košice Region. The regions are further subdivided into 79 districts.

\section{Stock density of selected livestock groups}

The dynamics of the changes in livestock farming between the years 2004 and 2017 is processed in form of analyses; the cartographic visualization consists of maps documenting the initial state (the year 2004) and the state in the year 2017. 


\section{Stock density of cattle - Situation in the year 2004 and 2017}

In the year 1993 more than 900000 heads of cattle were bred in Slovakia, in the year 2004 it was only 540146 heads and at present in the year 2017 the figure amounts to 439826 heads (when comparing the years 2004 and 2017 the decrease equals to 100 320 heads), which is a decline of $18.6 \%$. A decline over $30 \%$ was seen in the Nitra and Trnava Regions. All the regions reported a reduction in livestock population except for the Prešov Region, which recorded a moderate increase of $3.5 \%$. The milk producers keep on producing milk with a loss. The level of the purchase prices of milk does not cover the production costs, which are high. For instance in the year 2000 in Slovakia 246000 milking cows were bred and in the year 2017 it was roughly only 125000 . The drop in the numbers of cattle is also shown in stock density on the declared area, i.e. heads on 100 hectares of agricultural area. This indicator in the year 2004 amounted to 28 heads of cattle per 100 hectares of agricultural area and in the year 2017 it was only 23 , which results in a decrease of $17.7 \%$. The decrease of beef cattle numbers expressed by stock density was seen in all Slovak regions except for the Prešov Region (Fig. 1 and Fig. 2).

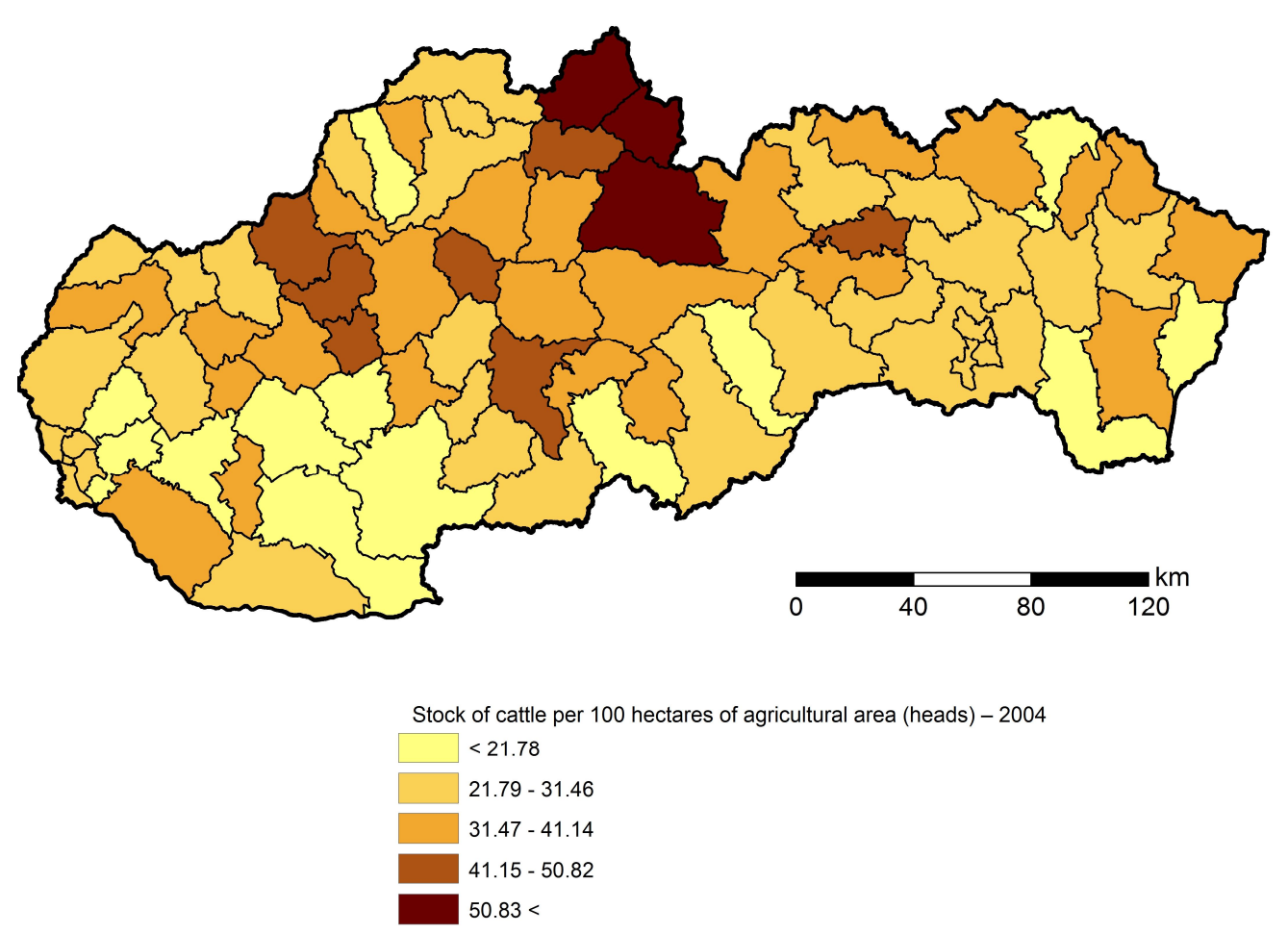

Figure 1. Stock of cattle per 100 hectares of agricultural area (heads) - 2004

The falling numbers of cattle influenced the structure of vegetable production particularly the production volume of grain feed and bulk feed. After the entry of Slovakia into the EU the subsidy policy had a positive impact on the breeding of suckler cows. This type of breeding is of relevance especially for landscape maintenance in the agriculturally disadvantaged regions. In the long run an increase of cattle numbers would bring positive results such as for instance the increase of the production of stable manure, which is increasingly lacking on Slovak soils. 


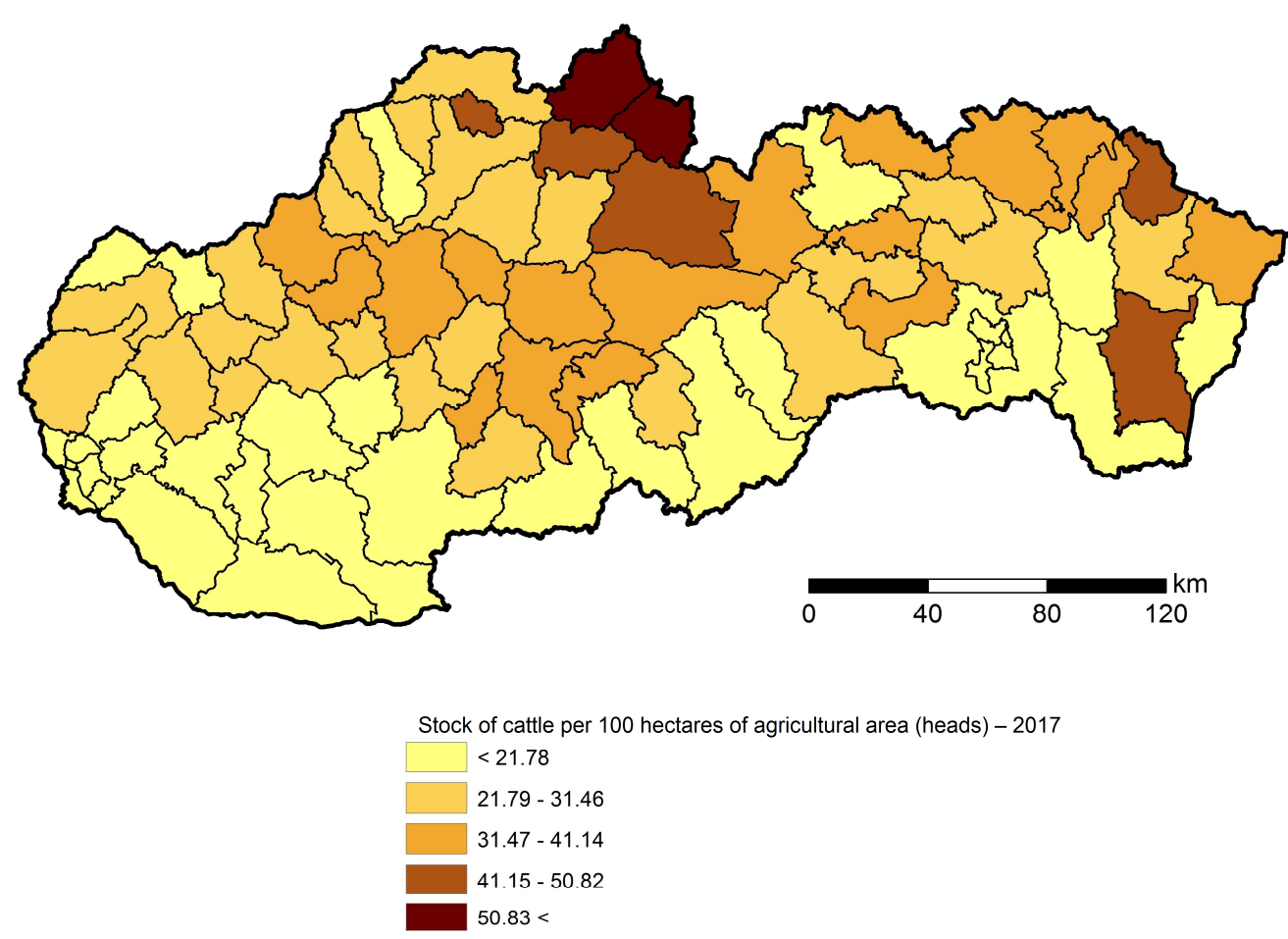

Figure 2. Stock of cattle per 100 hectares of agricultural area (heads) - 2017

\section{Stock density of pigs - Situation in the year 2004 and 2017}

In the year 1993 in Slovakia 1.8 million heads of pigs were bred. At the time when Slovakia was entering the EU it was 1,1 million heads and in the year 2017 it was only 614384 heads (a decrease of 534898 heads). This was the biggest decrease reported among all farm animals (-46.5\%). The numbers of pigs fell primarily due to the impossibility to receive subsidies in the field of pig farming as a consequence of the overall surplus production of pigs in the EU states. The next factor influencing the falling numbers of pigs was the increase of the prices of feed, lower purchase prices of pork and cheaper import of meat from abroad. The decrease of the numbers of pigs was seen in all the Slovak regions. In the Košice and Žilina Regions the decline exceeded 70\%. A decrease over 50\% was reported in the Banská Bystrica, Nitra and Trenčín Regions. Pork is being imported to Slovakia from almost all of Europe, however in particular from the neighbouring countries such as Poland, the Czech Republic and Hungary. More than $50 \%$ of the slaughter pigs are being exported due to the closing of a number of important slaugher houses. At the present day in Slovakia there are only smaller slaughter houses in operation such as for example in Myjava, Tešedíkov and Komárno. Most Slovakian slaughter houses process meat from foreign production, which is cheaper and thus more profitable. Slovakia attempts to revitalize the sector of pig farming, which was permanently ignored, with the help of subsidies coming either from the EU or the state itsself. Nowadays Slovakia is beginning to put more emphasis on the freshness and quality of meat, which cannot be guaranteed to the consumer in case of imported meat but only with meat produced by Slovak farmers. From the point of view of future development the growth potential in the area of pig breeding in Slovakia is obvious and it can be expected that the country will become fully 


$$
\text { - } 7654-
$$

sustainable in pork production. Also the stock density of pigs expressed in the numbers of pigs per 100 hectares of arable land points to a decrease of pig population during the reference period from 2004 to 2017. In Slovakia the stock of pigs in 2004 totalled to 84.5 heads, which in 2017 fell to 45.8 heads, which presents a decrese of $45.9 \%$. A significant decline of more than $70 \%$ was reported in the Košice and Žilina Regions (Fig. 3 and Fig. 4). The decrease in the numbers of pigs expressed by stock density of pigs was seen in all the regions of Slovakia.

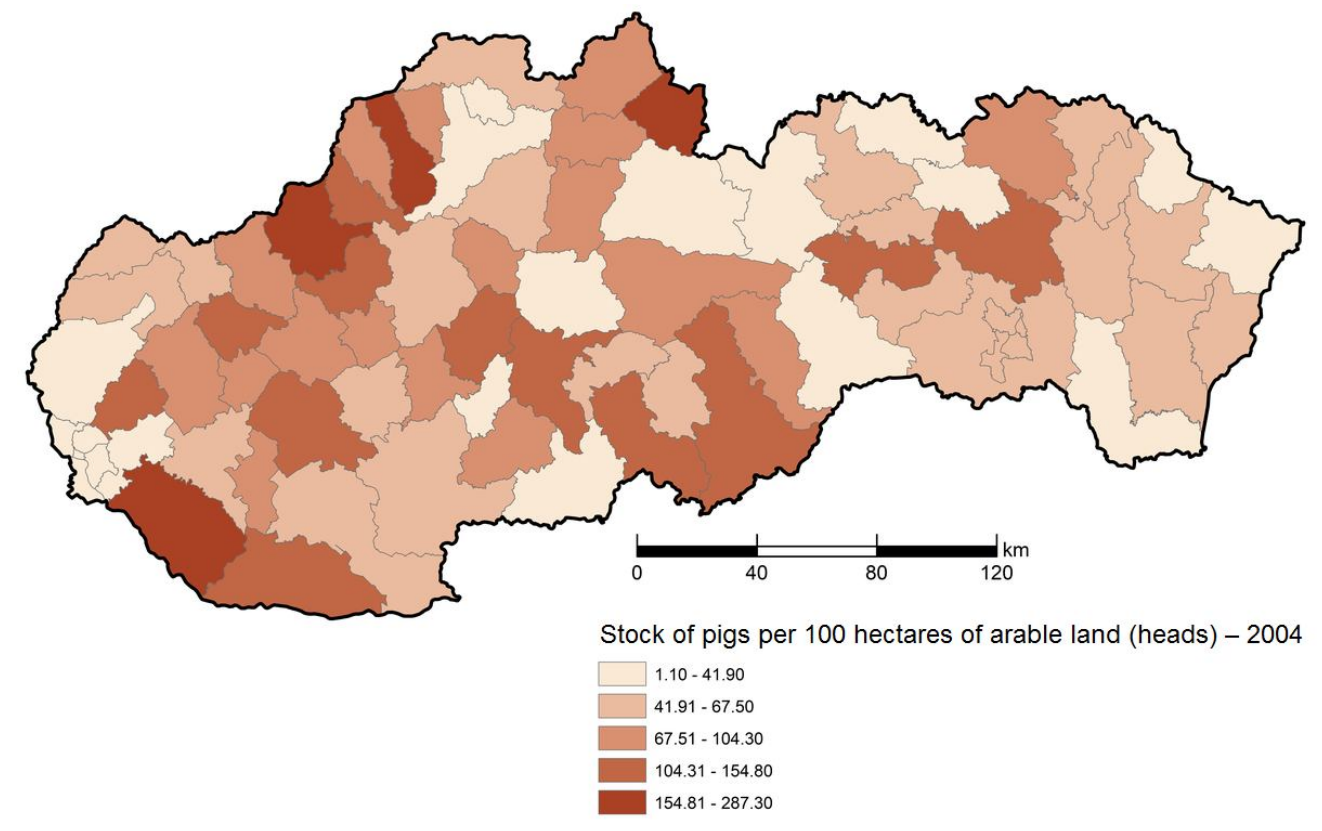

Figure 3. Stock of pigs per 100 hectares of arable land (heads) - 2004

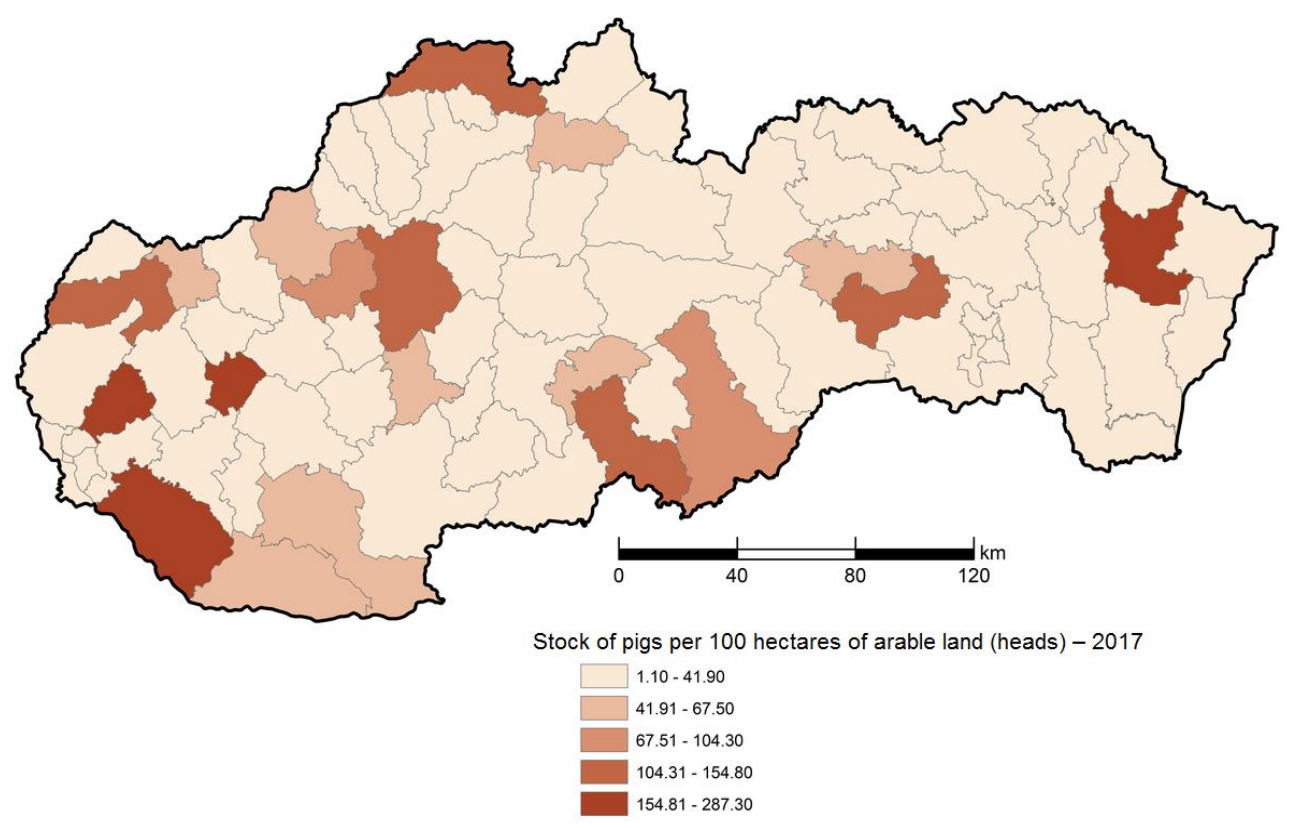

Figure 4. Stock of pigs per 100 hectares of arable land (heads) - 2017 


\section{Stock density of poultry - Situation in the year 2004 and 2017}

In case of poultry Slovakia did not record such a significant decline as with pigs and beef cattle. In the year 2004 in Slovakia 13.7 million heads of poultry were bred, before the year 2017 the numbers fell to 13.4 million heads $(-2.6 \%$, a decrease of 359402 heads). A bigger decline was seen in the Trnava Region $(-32.2 \%)$ and Prešov Region $(-53.9 \%)$. This decline can be attributed to the common European market connected with the import of cheaper poultry meat from abrod especially from Poland and Hungary. In consequence of the pressure by the supermarket chains regarding the reduction of poultry meat purchase prices, the price fell over several years and does not longer cover the production costs of the breeders. Prior to the year 2000 Slovakia was self-sustainable in the production of poultry meat. As of today the production of poultry meat covers approximately $50 \%$ of the consumption of the Slovak population. An increase of the numbers of poultry in the reference period from 2004 to 2017 was seen only in the Bratislava Region and Košice Region. In all the other Slovak regions we state a moderate decline. The decline in poultry numbers can be illustrated with a next indicator, stock density expressed by the number of heads per 100 hectares of arable land. In the year 2004 in Slovakia this value amounted to 1009.8 heads of poultry per 100 hectares of arable land, by 2017 the value went down to 994.4 heads, which presents a $1.5 \%$ decrease. The increase in poultry population in the Bratislava and Košice Regions is also reflected in the stock density of poultry (Fig. 5 and Fig. 6). According to this indicator the remaining regions report a decline.

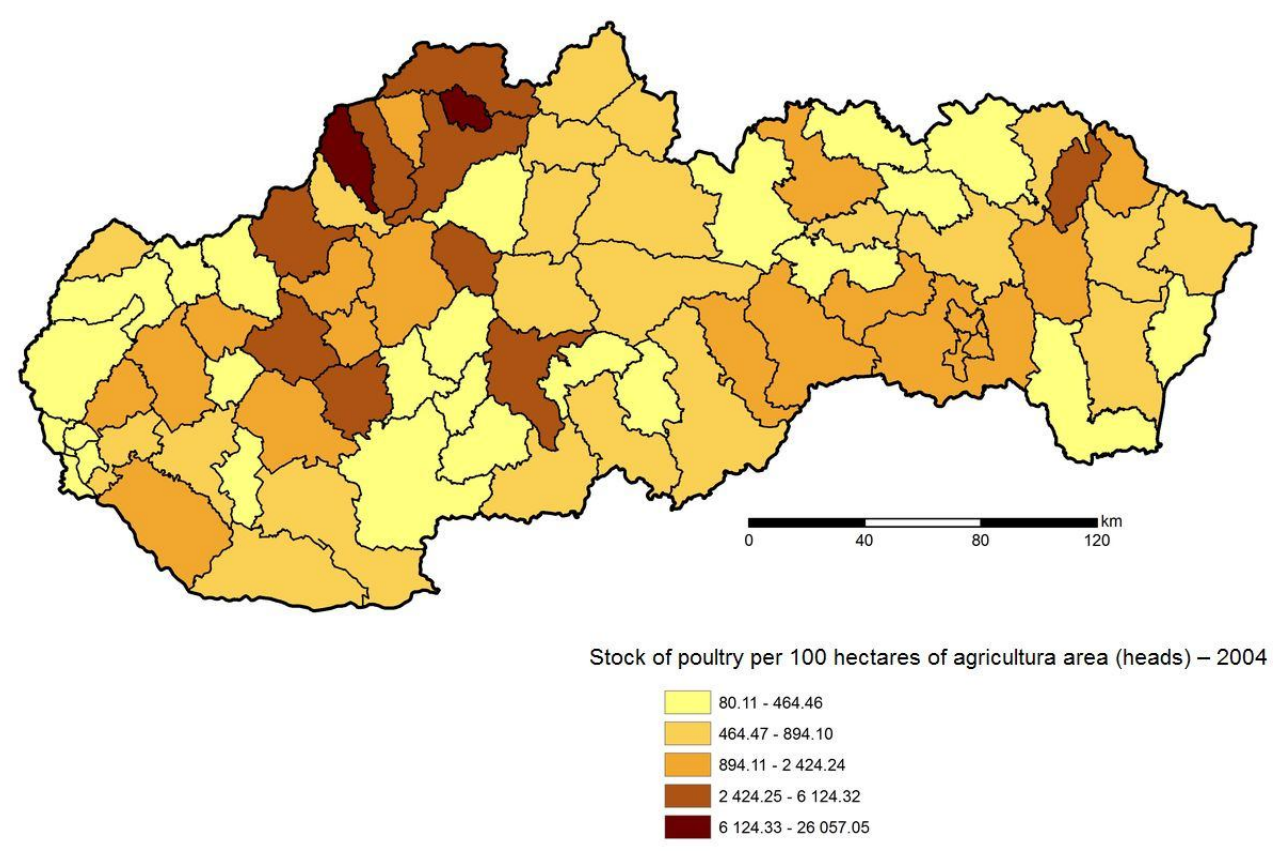

Figure 5. Stock of poultry per 100 hectares of agricultura area (heads) - 2004

\section{Stock density of sheep - Situation in the year 2004 and 2017}

In case of sheep Slovakia has seen a moderate increase of $13.7 \%$. In the year 2004 the numbers of sheep amounted to 321227 heads and in the year 2017 it was 365344 (an increase by 44117 heads). In all the regions of Slovakia the numbers of sheep 
increased in the reference period from 2004 to 2017. There was a decrease only in the Nitra Region (-15.1\%). The biggest increase was seen in the Bratislava Region $(93.3 \%)$ and the Trenčín Region (51.6\%). In the year 2004 there were 16.6 sheep on 100 hectares of agricultural area and by 2017 the value of the indicator went up to 19.1 heads (an increase by 15\%) (Fig. 7 and Fig. 8).

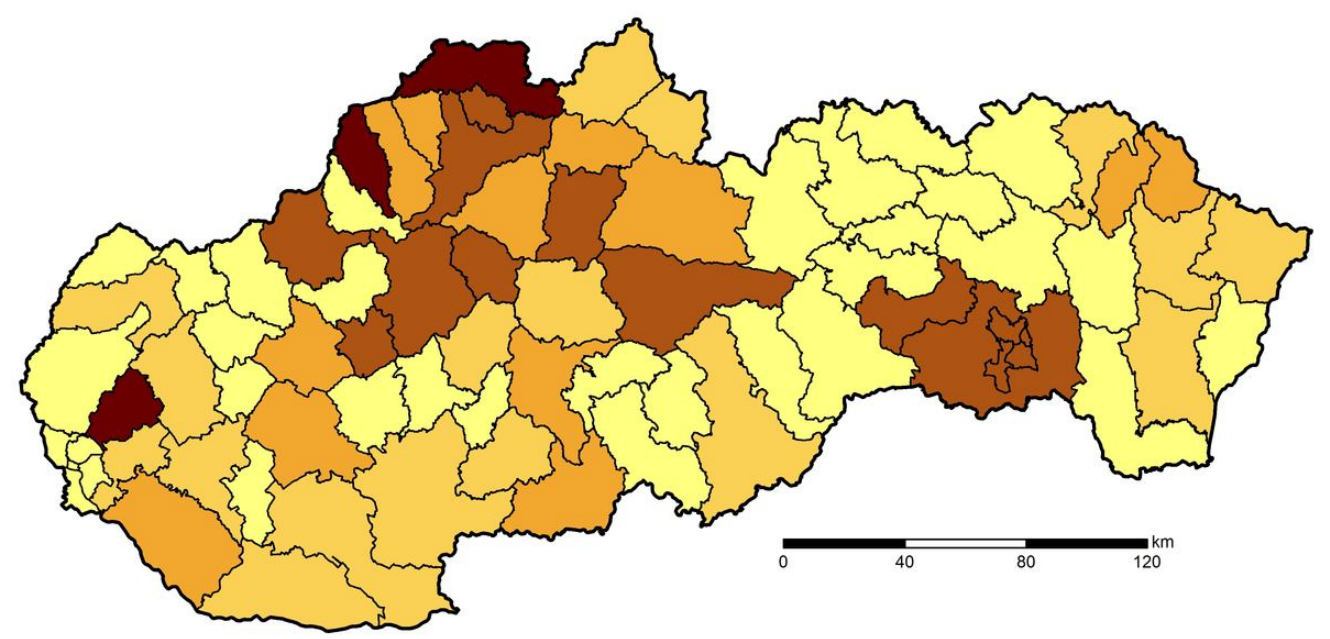

Stock of poultry per 100 hectares of agricultura area (heads) -2017

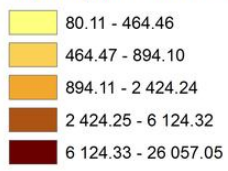

Figure 6. Stock of poultry per 100 hectares of agicultura area (heads) - 2017

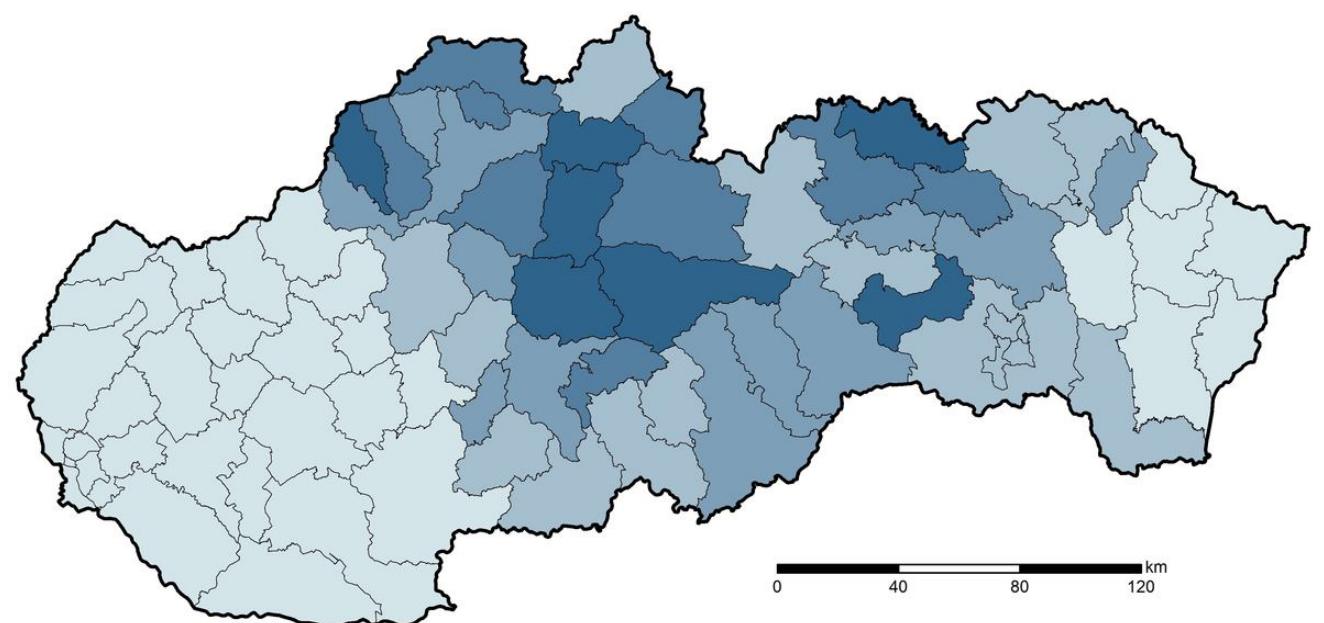

Stock of sheep per 100 hectares of arable land (heads) -2004
\begin{tabular}{|l|}
$\square$ \\
$0.04-9.33$ \\
$9.34-23.01$ \\
$23.02-39.47$ \\
$39.48-56.51$ \\
$56.52-91.55$
\end{tabular}

Figure 7. Stock of sheep per 100 hectares of arable land (heads) - 2004 
This was primarily due to the EU's supporting the breeding of farm animals on permanent grassland. The increase in numbers was seen in all the regions of Slovakia except the Nitra Region, in which the stock density of sheep fell by $16 \%$. The domestic consumer market is little interested in sheep meat and thus most of the production is being exported to the markets of developed EU countries. The subsidies and payments in relation to the area of permanent grassland in Slovakia will contribute to further expanding the sector of sheep breeding. Potential development model of stock density in the coming period (identification of expected trends) is presented bellow (Fig. 9).

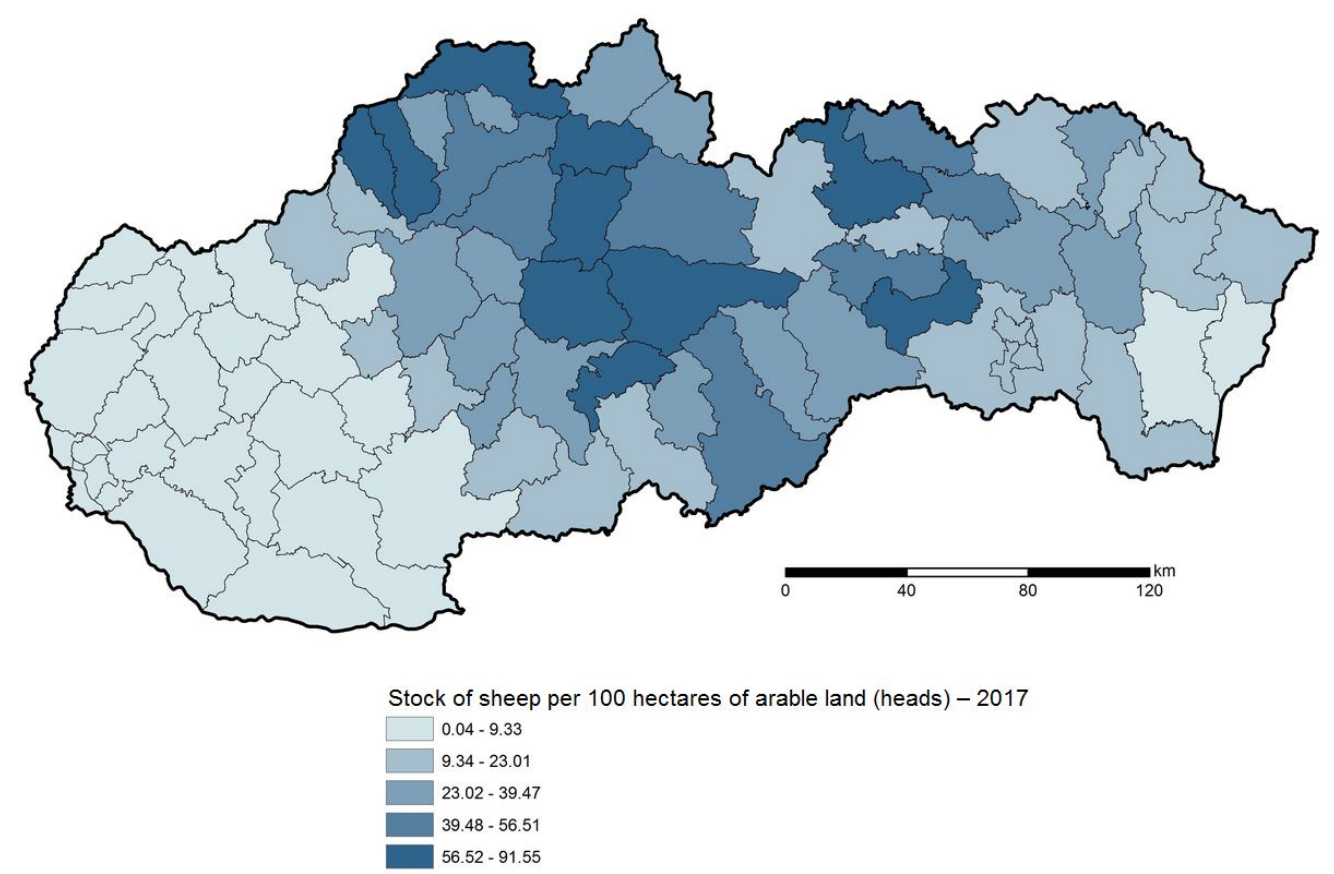

Figure 8. Stock of sheep per 100 hectares of arable land (heads) - 2017

\section{Dynamics of sales from livestock production over the period from 2004 to 2017 - share of livestock production sales in total sales from agriculture}

Over the past 30 years the breeding of farm animals in Slovakia has significantly decreased especially the breeding of pigs (by more than 66\%) and breeding of beef cattle (by more than 50\%). This negative phenomenon has translated into the falling employment rates in agriculture. After the accession to the EU Slovak agriculture has not sufficiently used its potential arising from the implementation of the CAP, the common European market and the two rural development programmes. The sector has been financially undernourished for a long period. Unequal conditions among EU countries have contributed to a further decrease of the numbers of farm animals, which led to Slovakia's not longer being self-sustainable in the field of meat production and meat processing. Also the fact can be seen as negative that the export of living farm animals abroad has increased due to the fact that Slovakia lacks meat-processing enterprises. A next reason is the lower redemption price of meat as compared with abroad. Slovakia is able to cover domestic meat consumption, however over the past years the import of farm animals and mainly the import of meat from abroad have been on the increase. The incorrectly set system of subsidies for livestock production as well 
as the milk crisis in 2015 made the population of farm animals gradually drop. The unequal level of support among the individual EU member states weakens the competitiveness of Slovak agriculture. A lower level of support on the part of the state does not create favourable conditions for running a farm business either. Slovak agriculture must have adequate conditions for enterprenial activities as it is the case with the other EU states. Livestock production in Slovakia has been on the decline and vegetable production is starting to gain the upperhand. In the year 2004 the share of livestock production sales in the total sales amounted to $58 \%$ and in the year 2017 it only made for $44 \%$. The lower share of livestock production in the total sales has been seen since the year 2009, when the livestock production sales amounted to $47.03 \%$ and the sales from vegetable production to $52.97 \%$. The share of livestock production sales in the total sales generated in the Slovak Republic reveals a decline in livestock production, as demonstrated of maps from the years 2004 and 2017 (Fig. 10 and Fig. 11). When comparing the years 2004 and 2017 the sales from livestock production in Slovakia fell by $7.6 \%$. The biggiest decrease was seen in the Trenčín Region (-20.7\%), the Banská Bystrica Region (-20.2\%) and the Nitra Region (-14.7\%).

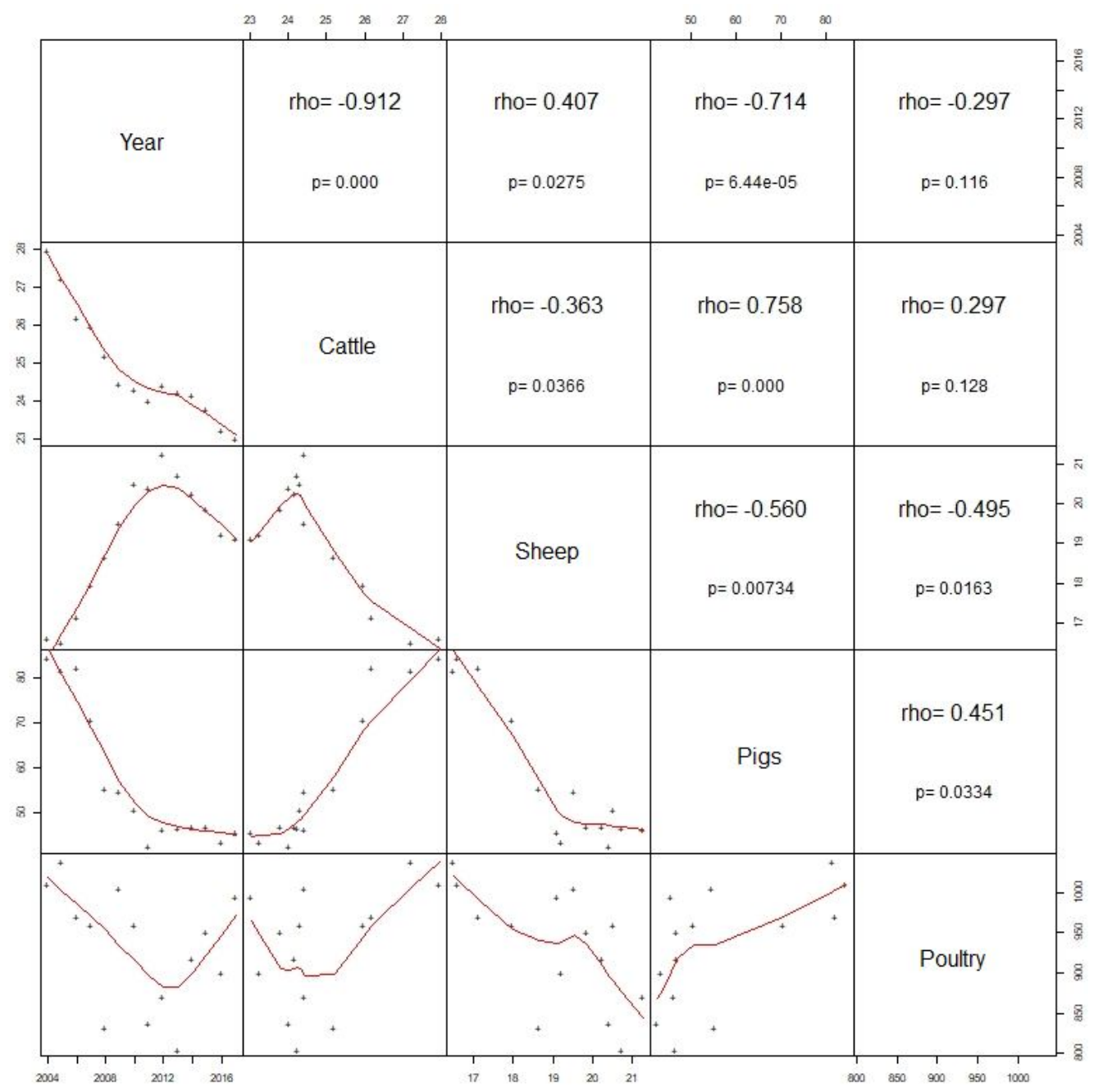

Figure 9. Animal production trends model in the Slovak Republic (model based on time series analysis) 


$$
-7659 \text { - }
$$
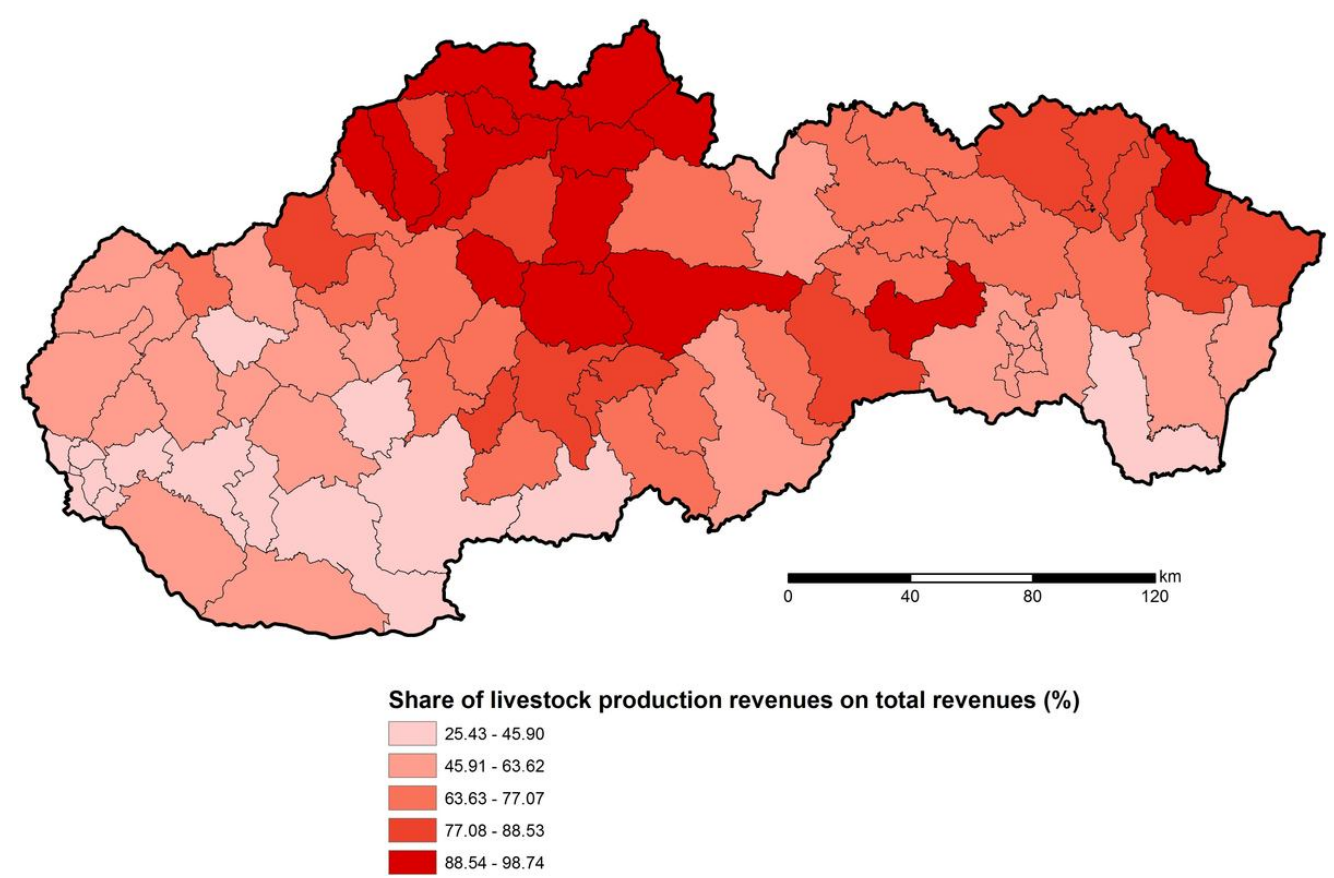

Figure 10. Share of livestock production revenues on total revenues (\%) - 2004

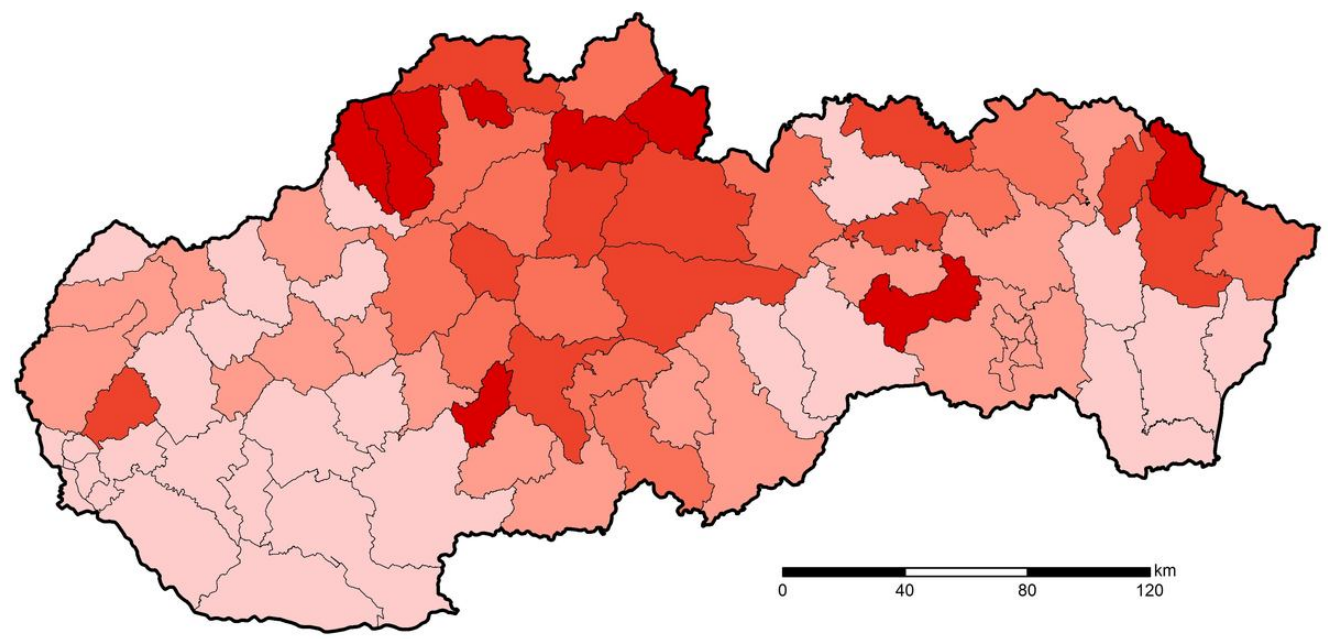

Share of livestock production revenues on total revenues (\%)

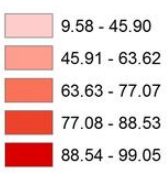

Figure 11. Share of livestock production revenues on total revenues (\%) - 2017

Vegetable production compared to livestock production is being more supported in Slovakia. According to the Ministry of Agriculture and Rural Development of the Slovak Republic, 2006 the direct payments into agriculture in Slovakia in the year 2005 amounted to 203 MioEUR, while less than 8 MioEUR went to livestock production. It is regarded as positive that the direct payments were gradually increasing and in the 
year 2016 they totalled to 408 MioEUR, from which the breeders of farm animals only received 54 MioEUR (Ministry of Agriculture and Rural Development of the Slovak Republic, 2017). The above-mentioned disproportion in funding the livestock production sector in form of a lower number of types of direct support from the EU could be alleviated by funding from the state budget; however this support can not be compared with the level of funding provided in the remaining EU states.

\section{Changes in livestock production and their potential impact on quality of environment}

The changes in livestock production in Slovakia between the years 2004 and 2017 may at first sight suggest a favourable development in reducing damage connected with the direct impact of the agrarian sector on the environment. In case of farm animal breeding it is the potential impact on air quality as well as the quality of soil and water sources. In this respect environmental pollution was particulary seen in relation to largecapacity agricultural farmyards but also with other activities carried out outside the premises of agricultural businesses. The decline in the population of farm animals might in this context appear as a naturally positive factor. However, in a broader context it is necessary to point out the importance of non-productive factors related to a targeted breeding of farm animals. These non-productive factors have a wider impact on the whole society but there is also their biological impact including the preservation of the cultural character of landscape and protection of the environment.

- Reduction of the population of farm animals decreased the production of biomass as renewable energy source and this not only in the form of excrements but also in form of reducing areas under crops for selected commodities, which belonged to the fodder base of livestock production as well as selected types of fermented feed (e.g. silage).

- Reduction of the population of farm animals made natural fertilizers such as the production of stable manure less accessible.

- Livestock production and farm animal breeding generate a quantity of greenhouse gases emissions such as carbon dioxide $\mathrm{CO}_{2}$ and nitrogen oxide. Most greenhouse gases are released into the air from stable manure. The decrease of the population of farm animals has a positive impact on the reduction of emissions responsible for the greenhouse effect.

- The falling population of farm animals reduces the levels of methane, which has a harmful impact on the climate.

- The drop in the population of farm animals also leads to lowering the level of ammonia $\left(\mathrm{NH}_{3}\right)$ emissions. Ammonia contributes to the creation of acid rains.

- Livestock production also causes damage and pollutes soil by excessive overgrazing of pastures by the farm animals and can thus provoke erosive soils. The reduction of the population of livestock therefore has a positive impact on soil.

- Livestock production further contributes to polluting waters. Ground water is mainly polluted by animal droppings, chemicals, synthetic fertilizers, pesticides, hormones and antibiotics that are being served to the animals with fodder. In this respect the decline in the population of farm animals has a positive impact on the environment.

- As it is stated in many documents of the European Union selected groups of farm animals (particularly sheep and beef cattle) play an irreplaceable role in 
form of ecological benefits because they help preserve biodiversity and landscape in areas that are naturally disadvantaged or less fertile. The preserveration of biodiversity affects both the flora and fauna and the whole ecosystems respectively. In many countries, Slovakia included, we find national as well as local breeds, which presents a unique gene pool from the point of view of reproduction and sustainability of the gene pool and animal genetic sources, which foregrounds also the impact on the protection and preservation of agrobiodiversity.

- Farm animals play an equally important role in fighting such phenomena as soil erosion particularly as a result of deforestation but also the changing structure of vegetation, avalanches, fires, inundations and torrential rainfalls.

- The grazing of natural pastures often prevents progradation of various air-raid/ invasive types of plantes (either herbs or woody plants), maintaining i.a. healthy vegetation from the point of view of assimilation of nutrients. Bad accessibility is also a relevant factor.

\section{Possibilities for development of organic farming with focus on livestock production}

A sustainable agroecosystem prioritizes organic farming practices, functions and objectives in farming on soil and breeding of animal farms. In comparison with the conventional methods of farming organic farming has more positive effects on the protection of natural elements and landscape. An indispensable factor is the biodiversity of the flora and fauna in areas with arable land, permanent grassland and in the surrounding biotopes as well as the preservation and protection of agrobiodiversity. Since Slovakia entered the EU organic farming has been booming as never before. The positive trend of the development of organic farming in Slovakia has been reflected in an increased number of producers of bioproducts, the area of organic soil has risen and the number of enterprises processing bioproducts has seen a moderate increase too. In the year 2017 there are more than 400 farms operating in the field of organic farming registered in Slovakia. The share in organically farmed land has increased up to $9 \%$. Also the demand of the consumers for organic products significantly contributes to the development of organic farming. In spite of the fact that the prices of organic products are not exactly low the present-day consumers are committed to eating healthy food and protecting their environment at the same time. An essential advantage of organic products is the fact that their production does not pollute the environment. On organic farms, where permanent grassland prevails, the breeding of beef cattle, sheep and goats is strongly represented. As to the orientation of livestock production in the regions of Slovakia it is particularly cattle breeding in combination with other types of farm animals such as sheep, goats and horses. When it comes to cattle breeding two central Slovakian regions stand out: the Žilina and Banská Bystrica Regions and also the Prešov and Košice Regions in eastern Slovakia. The breeding of sheep in combination with other farm animals is less represented (goats, horses and pigs). The farmers deal the least with the breeding of pigs and poultry. It is in this very type of breeding that Slovakia can develop a lot in future. In the Western Slovak Regions and in the Danubian Lowland organic breeding of farm animals is almost not being carried out. In Western Slovakia it is vegetable production of the conventional type but also alternative vegetable production that is more developed. As negative the fact can be regarded that there is an absence of the processors of organic products, their quantity is still not sufficient though the number is rising. As of 2017 Slovakia reports more than 80 
processors in the field of organic farming, while a majoritiy of the enterprises processing the products of organic farming are located in the regions of Western Slovakia, Eastern Slovakia and in the northern part of the country. These entities mainly concentrate on processing and producing dairy products (17 processors).

In the programming period from 2014 to 2020 the territory of Slovakia falls under the Rural Development Programme 2014 - 2020, which supports organic farming within Priority 4 "Restoring, preserving and enhancing ecosystems related to agriculture and forestry", measures 11 "Organic farming, sub-measures Payments for conversion to organic farming practices and methods" and "Payments for the preservation of organic farming practices and methods". In Slovakia organic farming can become an important element not only when it comes to increasing employment in rural areas, development of agrotourism and production of traditional organic food but in landscape maintenance in particular.

\section{Conclusions}

The entry of Slovakia into the European Union introduced new possibilities of receiving subsidies and non-refundable financial resources, which nonetheless did not slow down the falling trend in the population of farm animals particulary of cattle and pigs. Slovak agriculture would not only be helped by a higher level of support from the state budget but also if the direct EU funding were aligned, which would contribute to increasing the employment rates in rural areas and put an end to Slovakia's lagging behind the other EU countries. Slovakia's competitiveness on the common European market would increase, while the importation of food from abroad would decrease. The CAP for the period $2014-2020$ meant a revaluation of direct payments to farmers and of the rural development policy, a greener more ecologically oriented policy of the state, support of smaller farms and small farmers, the support of suckler cows breeding and last but not least the abolishing of the system of milk quotas, which is however related to an overproduction of milk and milk products on the European market. The new reform should enable gradual improvement of efficiency in agriculture and at the same time decrease the share of agrarian policy in the total EU budget (Common Agricultural Policy Reform 2014 - 2020, 2015).

In the new programming period 2014 - 2020 the Ministry of Agriculture of the Slovak Republic has decided to increase the financial support for the breeding of certain farm animals, e.g. milk cows, brood sows, pigs for fattening, broiler chicken and sheep. The amount of the subsidy is derived from the number of the specific animals and the costs necessary for their life (Rural Development Programme of the Slovak Republic 2014 - 2020, 2015). The main objective of this kind of support is to increase the numbers of farm animals in the individual types of breeding.

The funding from the European Union in the new programming period $2014-2020$ mainly targets revitalization of the dropping livestock production. Although at present Slovakia is not self-sustainable in the production of any kind of meat the country is capable of changing this situation. As far as the breeding of beef cattle is concerned the population of suckle cows is expected to grow. These changes are supported by the transfer of a part of arable land into permanent grassland. Slovakia has a considerable growth potential in the pig farming and there is the assumption to attain full selfsustainability in the production of pork and even to export it. The presently increasing interest of the consumers for poultry meat will contribute to increasing the domestic 
production of slaughtered poultry. Slovak consumers are minimally interested in purchasing sheep meat and most of the production is being exported to developed EU countries. It can be presumed that the breeding of sheep in Slovakia will increase due to support and payments according to the area of permanent grassland. Along with cattle farming sheep breeding is of considerable importance for a sustainable development of rural landscape in mountain and submontane regions. The Slovak consumer is increasingly more interested in not only the quality but also the origin of meat. The freshness of meat is a sign of quality and this cannot be guaranteed by any kind of imported meat. This is the reason why Slovakia endeavours to support young beginning farmers. Young farmers are expected to particularly develop the sensible sectors such as livestock production but also truck farming and fruit growing. It is these very products that are absent on the regional markets (Common Agricultural Policy Partnership between Europe and farmers, 2012). Hole et al. (2004) assess the impact of organic farming on landscape biodiversity compared to conventional farming. Intensification and expansion of modern agriculture rank among the biggest current threats to global biodiversity. Organic farming is a potential solution for increasing biodiversity. This system focusses on food production while minimally damaging the ecosystems. Slovakia meets the preconditions for further development of organic farming.

The dynamics of animal production from 2004 to 2017 in Slovakia, changes of its intensity and structure reflect wider changes in the context of the accession to the European Union and the application of common rules in the form of the CAP. As our study has shown, these changes has been significantly negative impact. The results, among other, are a livestock stocks decrease, a change in the share of livestock production revenues on total revenues, and a deepening of regional disparities. A systematic monitoring of the further development of livestock numbers/stocks (decline, stabilization, increase) and structure of animals / herds appears to be of importance. Furthermore, it will be important to monitor the impact of animal production development on total agricultural production and the agro-food complex, on the agricultural landscape, effect on the environment quality in the context of organic land management and sustainable land development.

Acknowledgements. This paper was elaborated within the project VEGA 1/0934/17 Land-use changes of Slovak cultural landscape over the past 250 years and prediction of its further development and project APVV-18-0185 Land-use changes of Slovak cultural landscape and prediction of its further development.

\section{REFERENCES}

[1] Brožová, I. (2011): The economic performance analysis of organic farms in the Czech Republic. - Agricultural Economics 57: 240-246.

[2] Buchenrieder, G., Möllers, J. (eds.). (2009): Structural change in Europe's rural regions, Farm livelihoods between subsistence orientation, modernisation and non-farm diversification. - Studies on the Agricultural and Food Sector in central and Eastern Europe, 49. - http://ageconsearch.umn.edu/bitstream/53334/2/IAMO\%20studies \%20series_vol49.pdf.

[3] Buday, Š., Chrastinová, Z., Krížová, S., Gálik, J. (2012): Porovnanie dopadov SPP na vývoj pol'nohospodárskej výroby a objem zahraničného obchodu. - Výskumný ústav ekonomiky pol'nohospodárstva a potravinárstva, Bratislava, 19p. 
[4] Chrastinová, Z., Trubačová, A., Ďuričová, I., Krížová, S. (2014): Ekonomická efektívnost' chovu hovädzieho dobytka a oviec. - Ekonomika pol'nohospodárstva XIV: 33-56.

[5] Common Agricultural Policy Partnership between Europe and farmers. (2012): Availabe at: https://ec.europa.eu/info/food-farming-fisheries/key-policies/common-agriculturalplicy/cap-glance.

[6] Common Agricultural Policy Reform 2014 - 2020 (2015): Available at: http://www.euractiv.sk/podnikanie-v-eu/zoznam_liniek/reforma-spolocnejpolnohospodarskej-politiky-2014--2020-000303.

[7] Doležalová, H., Pícha, K., Navrátil, J., Bezemková, A. (2014): Changes in the structure of the regional agricultural production (South Bohemian region). - Journal of Central European Agriculture 15: 335-353.

[8] Dos Santos, M. J. P. L., Henriques, P. D., Fragoso, R. M., Carvalho, M. L. P. V. (2010): Attitudes of the Portuguese farmers to the EU Common Agricultural Policy. Agricultural Economics 56: 460-469.

[9] Falt’anová, N. (2008): Očakávané vplyvy agrárnej politiky EÚ na vývoj pol'nohospodárskej výroby SR. - Prognostický ústav SAV, Bratislava.

[10] Gorton, S., Douarin, E., Davidova, S., Latruffe, L. (2008): Attitudes to agricultural policy and farming futures in the context of the 2003 CAP reform: A comparison of farmers in selected established and new member states. - Journal of Rural Studies 24: 322-336.

[11] Häring, A. M., Dabbert, S., Aurbacher, J., Bichler, B., Eichert, C. H., Gambelli, D., Lampkin, N., Offermann, F., Olmos, S., Tuson, J., Zanoli, R. (2004): Organic farming and measures of European agricultural policy. - Organic Farming in Europe: Economics and Policy, volume 11. University of Hohenheim, Stuttgart, 243p.

[12] Hole, D. G., Perkins, A. J., Wilson, J. D., Alexander, I. H., Grice, P. V., Evans, A. D. (2004): Does organic farming benefit biodiversity? - Biological Conservation 122: 113130.

[13] Hrabalová, A., Zander, K. (2006): Organic beef farming in the Czech Republic: structure, development and economic performance. - Agricultural Economics 52: 89-100.

[14] Ilbery, B., Maye, D. (2005): Alternative (shorter) food supply chains and specialist livestock products in the Scottish-English borders. - Environment and Planning A 37: 823-844.

[15] Kabrda, J., Jančák, V. (2006): České zemědělství a krajina po vstupu Česka do EU: nový institucionální rámec. - XXI. sjezd České geografické společnosti. České Budějovice.

[16] Kołodziejczak, A. (2006): Agriculture and the countryside in Poland: alternative scenarios of change. - Quaestiones Geographicae 25: 47-52.

[17] Kołodziejczak, A., Kossowski, T. (2011): Diversification of farming systems in Poland in the years 2006-2009. - Quaestiones Geographicae 30: 49-52.

[18] Kozáková, J., Lančarič, D., Tóth, M., Savov, R. (2015). Ekonomické zhodnotenie vybraných rozdielov ekologického a konvenčného hospodárenia na Slovensku. Ekonomika pol'nohospodárstva XV.

[19] Král, M., Palasová, P., Svobodová, H., Věžník, A. (2012): Dopady SZP EU na rozvoj zemědělství v centrální části Drahanské vrchoviny. - Geographia Cassoviensis VI: 78-90.

[20] Kulikowski, R. (2005): Agricultural problems areas, in Poland, 2002. - Moravian Geographical Reports 19: 50-60.

[21] Lockie, S., Halpin, D. (2005): The ‘Conventionalisation' Thesis Reconsidered: Structural and Ideological Transformation of Australian Organic Agriculture. - Sociologia Ruralis 45: 284-307. DOI:10.1111/j.1467-9523.2005.00306.x.

[22] Milestad, R., Darnhofer, I. (2003): Building farm resilience: The prospects and challenges of organic farming. - Journal of sustainable agriculture 22: 81-97. DOI:101300/J064v22n03_09. 
[23] Ministry of Agriculture and Rural Development of the Slovak Republic (2006): Správa o pol'nohospodárstve a potravinárstve v Slovenskej republike za rok 2005 (Zelená správa). - NPPC-VÚEPP, Bratislava, 257p.

[24] Ministry of Agriculture and Rural Development of the Slovak Republic (2017): Správa o pol'nohospodárstve a potravinárstve v Slovenskej republike za rok 2016 (Zelená správa). - NPPC-VÚEPP, Bratislava, 44p.

[25] Moschitz, H., Stolze, M. (2009): Organic farming policy networks in Europe: Context, actors and variation. - Food Policy 34: 258-264. DOI: 10.1016/j.foodpol.2009.03.007.

[26] Mzoughi, N. (2011): Farmers adoption of integrated crop protection and organic farming: Do moral and social concerns matter? - Ecological Economics 78: 1536-1545. DOI:http://dx.doi.org/10.1016/j.ecolecon.2011.03.016.

[27] Némethová, J., Mesárošová, J. (2013): The Development and Current Situation of Organic Farming in the Trnava Region, 2013. - Geographical Information 17: 4-25.

[28] Némethová, J., Dubcová, A., Kramáreková, H. (2014): The Impacts of the European Union's common agricultural policy in Slovakia. - Moravian Geographical Reports 22: 51-64. DOI: 10.1515/mgr-2014-0023.

[29] Némethová, J., Civáň, M. (2017): Regional differences in agriculture in Slovakia after its accession to the European union, 2017. - Quaestiones Geographicae 36: 9-21. DOI:10.1515/quageo- 2017-0011.

[30] Némethová, J., Dubcová, A., Kramáreková, H. (2017a): Slovak agriculture in 2002 2014 and its regional differentiations. - Geographical Journal 69: 281-298.

[31] Némethová, J., Dubcová, A., Nagyová, L., Kramáreková, H. (2017b): Ecological Farming in Slovakia and its Regional Disparities. - European Countryside 9: 746-768. DOI: $10.1515 /$ euco-2017-0042.

[32] Nieberg, H., Kuhnert, H. (2007): Support Policy for Organic Farming in Germany. Landbauforschung Völkenrode 57: 95-106.

[33] Petrovič, F., Stránovský, P., Muchová, Z., Falt’an, V., Skokanová, H., Havlíček, M., Gábor, M., Špulerová, J. (2017): Landscape-ecological optimization of hydric potential in foothills region with dispersed settlements - a case study of Nová Bošáca, Slovakia. Applied Ecology and Environmental Research 15: 379-400.

[34] Rudnicki, R. (2013): Spatial differences in the number of applications for payments under the EU common agrocultural policy submitted by agricultural holdings in Poland over the yers 2002-2010. - Quaestiones Geographicae 32: 15-31.

[35] Rural Development Programme of the Slovak Republic 2014 - 2020 (2015): Available at: $\mathrm{http} / / / \mathrm{www}$. pomocvidieku.sk/sites/default/files/program_rozvoja_vidieka_sr_2014_2020_-_neprojektove_opatrenia.pdf.

[36] S̄chlosserová, J., Juršík, J. (2009): Ekologické pol'nohospodárstvo. - Inštitút vzdelávania veterinárnych lekárov, Košice, $88 \mathrm{p}$.

[37] Spišiak, P., Kusendová, D., Pavličková, K., Halás, M., Kolény, M., Zubriczký, G., Švoňavec, M., Hurbánek, P., Palúch, T., Labuda, M. (2005): Agrorurálne štruktúry Slovenska po roku 1989. - Bratislava, Geo-grafika.

[38] Spišiak, P., Némethová, J. (2008): Agrosubjekty regiónu Nitra vo vzt'ahu k odberatel'om pol'nohospodárskych surovín $=$ Agricultural entities of the Nitra region in relation to the purchasers of agricultural raw materials, 2008. - Geographical Journal 60: 63-87.

[39] Stolze, M., Lampkin, N. (2009): Policy for organic farming: Rationale and concepts. Food Policy 34: 237-244.

[40] Svobodová, H., Věžník, A. (2011): Impacts of the commom agricultural policy of the European union in the Vysočina region (Czech republic) by the view of the farmers. Journal of Central European Agriculture 12: 733-743.

[41] Věžník, A., Konečný, O. (2011): Agriculture of the Czech republic after accession to the EU: regional differentiation. - Moravian Geographical Reports 19: 50-60.

[42] Věžník, A., Král, M., Svobodová, H. (2013): Agriculture of the Czech republic in the 21st century: From productivism to post-productivism. - Quaestiones Geographicae 32: 7-14. 
[43] Věžník, A., Svobodová, H., Némethová, J., Hradický, J. (2017): Livestock production in Czechia and Slovakia, ten years beyond EU accession, 2017. - Human Geographies: Journal of Studies and Research in Human Geography 11: 77-94. DOI: 10.5719/hgeo.2017.111.5. 